\title{
Effect of Brewers' spent grain (BSG) phenolic extracts on cell viability and protective effect against oxidant-induced DNA single strand breaks in U937 cells
}

Brewers' spent grain (BSG) is the solid portion of barley malt which remains following wort production for the brewing industry. Black barley (roasted to $200^{\circ} \mathrm{C}$ ) or pale barley (unroasted) is used for the brewing process, resulting in black or pale BSG ${ }^{(1)}$. BSG is a potentially useful source of phenolic acids following a published extraction procedure ${ }^{(2)}$. The alkaline-extracted phenolic acids have been shown to possess antioxidant activity ${ }^{(2)}$. The aim of this research was to determine antioxidant effects of BSG phenolic extracts following an enzymatic extraction process.

The BSG extracts were derived from either dry or wet BSG and were either black (labelled A-F) or pale (labelled G-J). The 3-(4, 5-dimethylthiazol-2-yl)-2, 5-diphenyltetrazolium bromide (MTT) assay was used to assess the effect of extracts on U937 cell proliferation at concentrations ranging from $0-20 \%(\mathrm{v} / \mathrm{v})$. The antioxidant effect of the extracts was measured by determining the DNA protective effects of the extracts in U937 cells exposed to $\mathrm{H}_{2} \mathrm{O}_{2}$, using the Comet assay.

\begin{tabular}{|c|c|c|c|c|c|}
\hline & \multicolumn{2}{|c|}{ DNA damage $(\%$ tail DNA) } & & \multicolumn{2}{|c|}{ DNA damage $(\%$ tail DNA) } \\
\hline & Mean & SD & & Mean & SD \\
\hline Control & $6.8^{*}$ & 1.7 & $\mathrm{~F}$ & $35.4 *$ & 3.6 \\
\hline $\mathrm{H}_{2} \mathrm{O}_{2}$ & $60 \cdot 8$ & $5 \cdot 0$ & G & $36 \cdot 0^{*}$ & 15.9 \\
\hline $\mathrm{A}$ & 36.5 & $13 \cdot 4$ & $\mathrm{H}$ & $38.9 *$ & 9.7 \\
\hline B & $23.0^{*}$ & 4.0 & I & 45.2 & $15 \cdot 4$ \\
\hline C & 37.0 & $12 \cdot 7$ & $\mathrm{~J}$ & $36.8^{*}$ & $14 \cdot 1$ \\
\hline D & 39.0 & 14.6 & FA & $31 \cdot 3^{*}$ & $4 \cdot 1$ \\
\hline E & $31.4 *$ & 0.3 & & & \\
\hline
\end{tabular}

DNA damage in U937 cells exposed to $75 \mu \mathrm{M} \mathrm{H}_{2} \mathrm{O}_{2}$ for 30 minutes following 24 hour incubation with brewers' spent grain extracts $(0 \cdot 1 \%$ or $2.5 \%$ v/v black extracts; $4 \% \mathrm{v} / \mathrm{v}$ pale extracts) or Ferulic acid (FA) $(1 \mu \mathrm{g} / \mathrm{ml})$. Values are mean of at least two independent experiments. Statistical analysis by ANOVA followed by Dunnett's test. *Denotes significant difference $(\mathrm{P}<0 \cdot 05)$ in DNA damage relative to $\mathrm{H}_{2} \mathrm{O}_{2}$ control.

In general, pale BSG phenolic extracts (G-J) (IC 50 values $19 \cdot 60-45 \cdot 02 \% \mathrm{v} / \mathrm{v}$ ) were less cytotoxic than black BSG extracts (A-F) $\left(\mathrm{IC}_{50}\right.$ values $\left.0.06-7.01 \% \mathrm{v} / \mathrm{v}\right)$ in U937 cells (data not shown). Preliminary results suggest that phenolic extracts can reduce $\mathrm{H}_{2} \mathrm{O}_{2}$-induced DNA damage in U937 cells. Previous research suggested that black BSG phenolic extracts had a greater DNA protective effect compared to pale BSG phenolic extracts ${ }^{(2)}$, however, results presented here demonstrated that there were no marked differences between black and pale extracts. This may be due to the lower concentration of black BSG phenolic extracts used in the present study $(0.1 \% \mathrm{v} / \mathrm{v})$. In conclusion, these results suggest that phenolic extracts when prepared from BSG using enzymatic procedures possess good antioxidant activity in U937 cells.

This research was supported through the Food Institutional Research Measure, administered by the Department of Agriculture, Food and the Marine, Ireland.

1. McCarthy AL, O' Callaghan YC, Neugart S, et al. (2013) Food Chem 141, 2567-74.

2. McCarthy AL, O' Callaghan YC, Connolly A, et al. (2012) Food Chem 134, 641-646 